\title{
AJARINCODE : APLIKASI PEMBELAJARAN BAHASA PEMROGRAMAN BERBASIS WEB
}

\author{
Ni Gusti Ayu Putu Harry Saptarini ${ }^{1)}$, Reza Akbar Hidayat ${ }^{2)}$, dan Putu Indah Ciptayani ${ }^{3)}$ \\ 1,2,3 Jurusan Teknik Elektro, Politeknik Negeri Bali, Kampus Bukit Jimbaran, \\ Kuta Selatan, Badung - Bali, Kode Pos 1064 Tuban \\ E-mail: ${ }^{1}$ ayu.harry@pnb.ac.id
}

\begin{abstract}
Abstrak - Bahasa pemrograman merupakan suatu subjek yang sangat populer saat ini. Pembelajaran bahasa pemrograman dapat dilakukan melalui pendidikan formal maupun informal seperti lembaga kursus atau pembelajaran secara online. Pembelajaran secara online memberikan berbagai keunggulan, diantaranya biaya yang lebih murah, waktu yang fleksibel dan setiap peserta dapat menyesuaikan dengan kemampuan dan perkembangan belajarnya. AjarinCode dibangun untuk membantu para pembelajar online dalam memahami bahasa pemrograman, khususnya bahasa pemrograman website yang meliputi PHP, HMTL, CSS, dan MySQL. Aplikasi ini akan memberikan materi sesuai dengan level pemahaman peserta, dan di setiap akhir pembelajaran akan diberikan ujian online dengan metode pengacakan soal menggunakan algoritma Fisher-Yates. Dengan algoritma ini, maka urutan soal yang dimunculkan akan selalu berbeda antara setiap peserta dan ketika seorang peserta mengulangi ujian. Peserta yang telah menyelesaikan ujian, nantinya akan dapat menempuh materi pada level lebih lanjut.
\end{abstract}

Kata Kunci: algoritma Fisher-Yates, pembelajaran online, pemrograman

\section{PENDAhuluan}

Bahasa pemrograman merupakan sebuah alat komunikasi antara manusia dengan perangkat komputer. Saat ini perkembangan teknologi. Bahasa pemrograman telah menjadi sebuah primadona tersendiri. Bahasa dibagi menjadi pemrograman tiga bagian, bahasa pemrograman tingkat rendah (low level programming language), bahasa pemrograman tingkat menengah (middle level programming language), bahasa pemrograman tingkat tinggi (high level programming language). Saat ini yang paling banyak mengalami perkembangan adalah bahasa pemrograman tingkat tinggi. Tercatat sejak kemunculan bahasa $\mathrm{C}$ yang dibuat oleh Dennis Ritchie, yang kemudian menjadi pondasi dari beberapa bahasa pemrograman seperti Java (James Gosling), C++ (Bjarne Stroustrup), PHP (Rasmus Lerdorf), dab sebagainya.

Untuk menekuni dan mempelajari bahasa pemrograman di Indonesia, dapat dilakukan dengan menempuh Pendidikan di perguruan tinggi baik negeri maupun swasta dengan focus pembelajaran pada bahasa pemrograman tertentu yang menjadi standar kompetensi. Ada juga yang menawarkan kelas kursus yang dibuka oleh sekelompok atau pun secara perorangan oleh programmer sendiri yang tentunya dengan biaya yang jauh lebih terjangkau daripada di perguruan tinggi.

Metode pembelajaran yang telah disebutkan pada paragraf sebelumnya memiliki beberapa kekurangan. Terbatasnya waktu belajar, materi yang di dapat kurang fleksibel, biaya yang masih mahal, dan adanya ketentuan pada perguruan tinggi yang mengharuskan pelajarnya untuk SMA hanya lulusan IPA, dan lulusan SMK di bidang computer(RPL, TKJ, dsb) yang bisa menempuh di jalur Pendidikan tinggi. Hal tersebut menjadi salah faktor penghambat seseorang untuk belajar bahasa pemrograman dan sulitnya menyerap tenaga kerja di bidang programmer di Indonesia.

Adanya beberapa kekurangan tersebut maka dibutuhkan aplikasi pembelajaran yang dapat meminimalisir kekurangan-kekurangan tadi. Aplikasi pembelajaran merupakan alat bantu untuk mengatasi kekurangan-kekurangan yang ada saat ini. Aplikasi pembelajaran ini memiliki beberapa fitur, salah satunya adalah fitur tes yang digunakan untuk melihat batas kemampuan sesorang dan digunakan sebagai indicator untuk naik level. Pada fitur tes ini digunakan sebuah algoritma pengacakan, yaitu algoritma FisherYates. Algoritma ini digunakan untuk mengacak posisi soal agar soal yang di dapat oleh setiap user tidak sama. Penggunaan algoritma ini sebelumnya sudah pernah dilakukan oleh Supriadi, dkk(2017), Ekojono, dkk(2017), Imam Haditama, dkk(2016). Dimana algoritma FisherYates mampu mengatasi permasalahan pengacakan ganda, dan menghasilkan hasil yang lebih bervariatif. Dengan penerapan algoritma ini pada fitur tes dapat mengatasi tingkat kecurangan pengerjaan dan menghasilkan indikator tingkat pemahaman yang sesuai.

\section{METODE PENELITIAN}

Objek penelitian ini adalah penentuan soal yang ditampilkan kepada user yang terdapat dalam aplikasi. Data dalam penelitian ini meupakan data premier. Data primier di dapat berdasarkan materi yang juga terdapat dalam aplikasi.

Pengguna aplikasi ini adalah admin, mentor dan peserta. Dimana peserta merupakan user yang belajar, mentor adalah user yang membantu peserta jika mengalami kesulitan saat belajar, admin merupakan pengontrol aplikasi. Aplikasi yang dibangun bersifat sebagai sarana belajar 
dengan menyuguhkan materi berdasarkan tingkat pemahaman peserta dan tes untuk mengukur tingkat pemahaman. Untuk mempermudah penggunaan aplikasi yang akan dibangun akan memiliki kemampuan fungsional sebagai berikut:
a. Fitur register / buat akun
b. Fitur materi
c. Fitur tes
d. Fitur event
e. Fitur tanya code

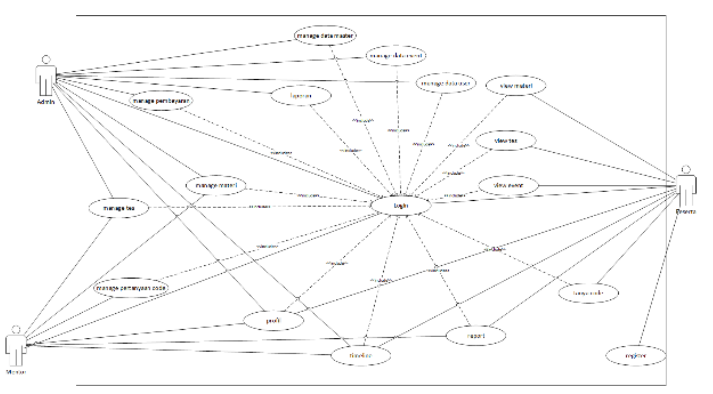

Gambar 1. Use Case Diagram

Untuh lebih jelasnya bisa dilihat pada use case diagram (gambar 1).

Metode yang digunakan untuk mengacak soal disini menggunakan algoritma Fisher-Yates. Proses pengacakan dengan menggunakan algoritma Fisher-Yates dapat dilihat pada gambar 2.

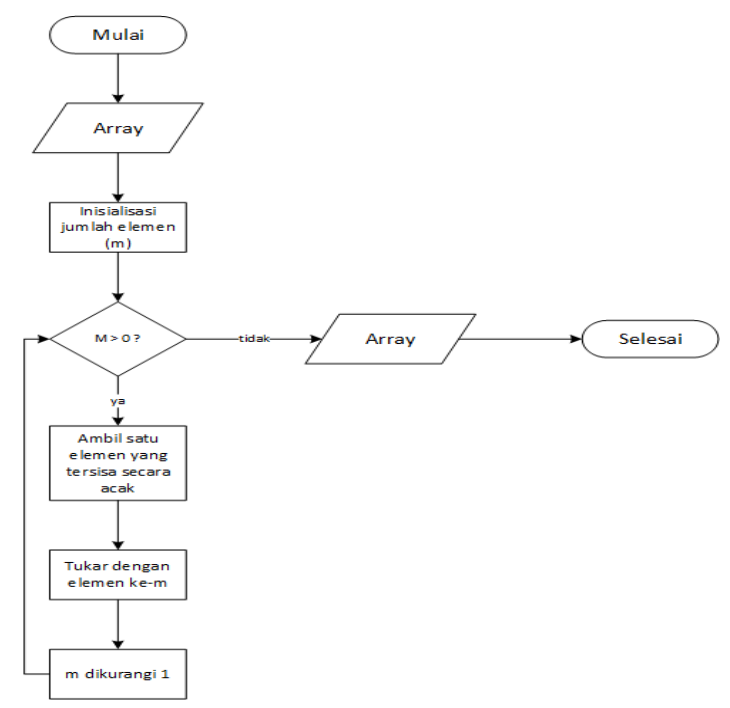

Gambar 2. Flowchart Algotihm Fisher-Yates

\section{HASIL DAN PEMBAHASAN}

Untuk memastikan hasil dari pengacakan dengan menggunakan algoritma Fsiher-Yates, maka dilakukan pengujian, dengan cara membuka soal dengan menggunakan beberapa user. Hasil dari penggunaan algoritma Fisher-Yates ini dapat dilihat pada table 1 .

Tabel 1. Analisa Algoritma Fisher-Yates

\begin{tabular}{c|c|c|c}
\hline Range & Roll & Scratch & Hasil \\
\hline & & $1,2,3,4,5,6,7,8,9,10$ & 4 \\
\hline $1-10$ & 4 & $1,2,3,10,5,6,7,8,9$ & 1,4 \\
\hline $1-9$ & 1 & $9,2,3,10,5,6,7,8$ & $6,1,4$ \\
\hline $1-8$ & 6 & $9,2,3,10,5,8,7$ & $8,6,1,4$ \\
\hline $1-7$ & 8 & $9,2,3,10,5,7$ & $3,8,6,1,4$ \\
\hline $1-6$ & 3 & $9,2,7,10,5$ & $9,3,8,6,1,4$ \\
\hline $1-5$ & 9 & $5,2,7,10$ & $2,9,3,8,6,1,4$ \\
\hline $1-4$ & 2 & $5,10,7$ & $10,2,9,3,8,6,1,4$ \\
\hline $1-3$ & 10 & 5,7 & $5,10,2,9,3,8,6,1,4$ \\
\hline $1-2$ & 5 & 7 & $7,5,10,2,9,3,8,6,1,4$ \\
\hline \multicolumn{4}{|c}{ Hasil akhir }
\end{tabular}

Berdasarkan hasil uji algoritma pada table 1. Maka hasil dari 10 kali percobaan dapat dilihat pada table 2 berikut. Percobaan dilakukan dengan mengacak 10 soal dan menampilkan 7 soal.

Tabel 2. Hasil pengacakan soal berdasarkan Algoritma

\begin{tabular}{c|l}
\multicolumn{2}{c}{ Fisher-Yates } \\
\hline Uji Coba & \multicolumn{1}{c}{ Hasil } \\
\hline Hasil ke-1 & $10,3,4,8,6,7,9$ \\
\hline Hasil ke-2 & $4,6,8,6,9,3,2$ \\
\hline Hasil ke-3 & $6,7,5,10,2,9,8$ \\
\hline Hasil ke-4 & $3,4,8,5,10,7,2$ \\
\hline Hasil ke-5 & $2,5,4,1,7,9,6$ \\
\hline Hasil ke-6 & $7,1,9,8,3,4,10$ \\
\hline Hasil ke-7 & $8,9,2,6,3,1,4$ \\
\hline Hasil ke-8 & $3,9,4,2,6,7,10$ \\
\hline Hasil ke-9 & $6,4,10,5,9,8,1$ \\
\hline Hasil ke-10 & $3,6,9,1,2,7,10$ \\
\hline
\end{tabular}

Berdasarkan hasil uji coba yang dilakukan sebanyak 10 kali bisa dilihat pada tabel 2 diatas, algoritma Fisher-Yates telah berhasil mengacak soal. Dan dari 10 kali percobaan dapat dipastikan hampir posisi soal yang di dapat berbeda-beda.

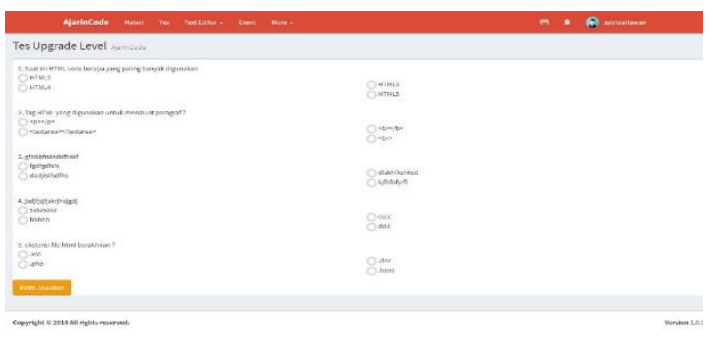

Gambar 3. Hasil pengacakan soal pada user 1 
Berikut hasil implementasi penggunaan algoritma Fisher-Yates pada gambar 3, gambar 4, dan gambar 5 .

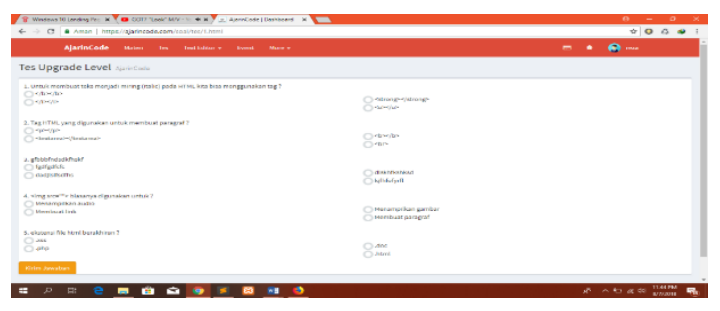

Gambar 4. Hasil pengacakan soal pada user 2

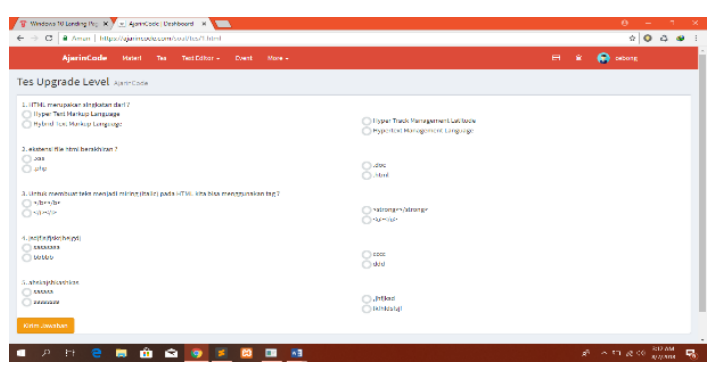

\section{SIMPULAN}

Dalam perancangan sistem digunakan UML (Unified Modelling Language) sebagai alat bantu pengembangan dimana salah satunya adalah use case diagram. Dalam pembuatan use case diagram menghasil 3 aktor yaitu admin, mentor dan peserta, serta terdapat 17 use case.

Pengacakan soal yang dilakukan dengan mengimplementasikan algoritma Fisher-Yates pada aplikasi pembelajaran telah berhasil dilaksanakan, dengan hasil dimana antar user mendapatkan penempatan no soal yang berbedabeda.

Perancangan aplikasi dilakukan dengan beberapa tahap berdasarkan SDLC (System Development Life Cycle) dimulai dengan menganalisa kebutuhan sistem dan melakukan perancangan dengan bantuan UML (Unified Modelling Language) dan ERD (Entity Relationship Diagram) untuk pembuatan database. Dan terakhir melakukan pengimplementasian sistem menggunakan bahasa pemrograman PHP dengan bantuan framework Codeigniter. Sehingga dapat dihasilkan sebuah "Aplikasi Pembelajaran Bahasa Pemrograman Berbasis Web".

\section{REFERENSI}

[1] Ade Ibijola \& Abejila. (2012). "A Simulated Enhancement of Fisher-Yates Algorithm for Shuffling in Virtual Card Games Using Domain-
Specific Data Structures". Dept Of Computer Science, Nigeria.

[2] Alhamidi. (2015). "Mengukur Kemampuan Bahasa Inggris Siswa Sekolah Menengah Atas Dengan Menggunakan Aplikasi Computer Based Testing (CBT)", Dept STMIK Jayanusa Padang, ISSN : 2338-2724.

[3] Arief Hidayat \& Bayu Surarso. (2013). "Penerepan Aristektur Model View Controller (Mvc) Dalam Rancang Bangun Sistem Kuis Online Adaptif'. SENTIKA, 10, 57 - 64.

[4] Budi Raharjo. (2016). "Modul Pemrograman Web (HTML, PHP, \& MySQL)", Edisi 3, Bandung: Modula.

[5] Ekojono, Dyah Ayu Irawati, Lugman Affandi, \& Anugrah Nur Rahmanto. (2017). "Penerapan Algoritma Fisher - Yates Pada Pengacakan Soal Game Aritmatika". SENTIA, 9, 95 - 100.

[6] Imam Haditama, Cepy Slamet, \& Deny Fauzy Rahman. (2016). "Implementasi Algoritma Fisher-Yates dan Fuzzy Tsukamoto Dalam Game Kuis Tebak Nada Sunda Berbasis Android". JOIN, 1, 51 - 58.

[7] Mhd Arief Hasan, Supriadi, \& Zamzami. (2017). "Implementasi Algoritma Fisher-Yates Untuk Mengacak Soal Ujian Online Penerimaan Mahasiswa Baru (Studi Kasus : Universitas Lancang Kuning Riau)”. Jurnal Teknologi dan Sistem informasi, 3, $291-298$.

[8] Priyanto Hidayatullah \& Jauhari Khairul Kawistara. (2017). "Pemrograman Web". Edisi Revisi, Bandung:Informatika.

[9] Samiaji Sarosa. (2017). "Metodologi Pengembangan Sistem Informasi". Jakarta:Indeks.

[10] Sidik \& Betha. (2012). "Framework Codeigniter”, Bandung:Informatika.

[11] Sugiarti, Yuni. 2013. Analisis dan Perancangan UML (Unified Modelling Language) Generated VB.6 Disertai Contoh Studi Kasus dan Interface Web. Yogyakarta: Graha Ilmu.

[12] Suprapto. (2008). "Bahasa Pemrograman Untuk Sekolah Menengah Kejuruan”. Jakarta, Direktorat Pembinaan Sekolah Menengan Kejuruan.

[13] Tapan Kumar, et all. (2015). "File Encryption Using Fisher-Yates Shuffle". Dept of Information Technology, India. 